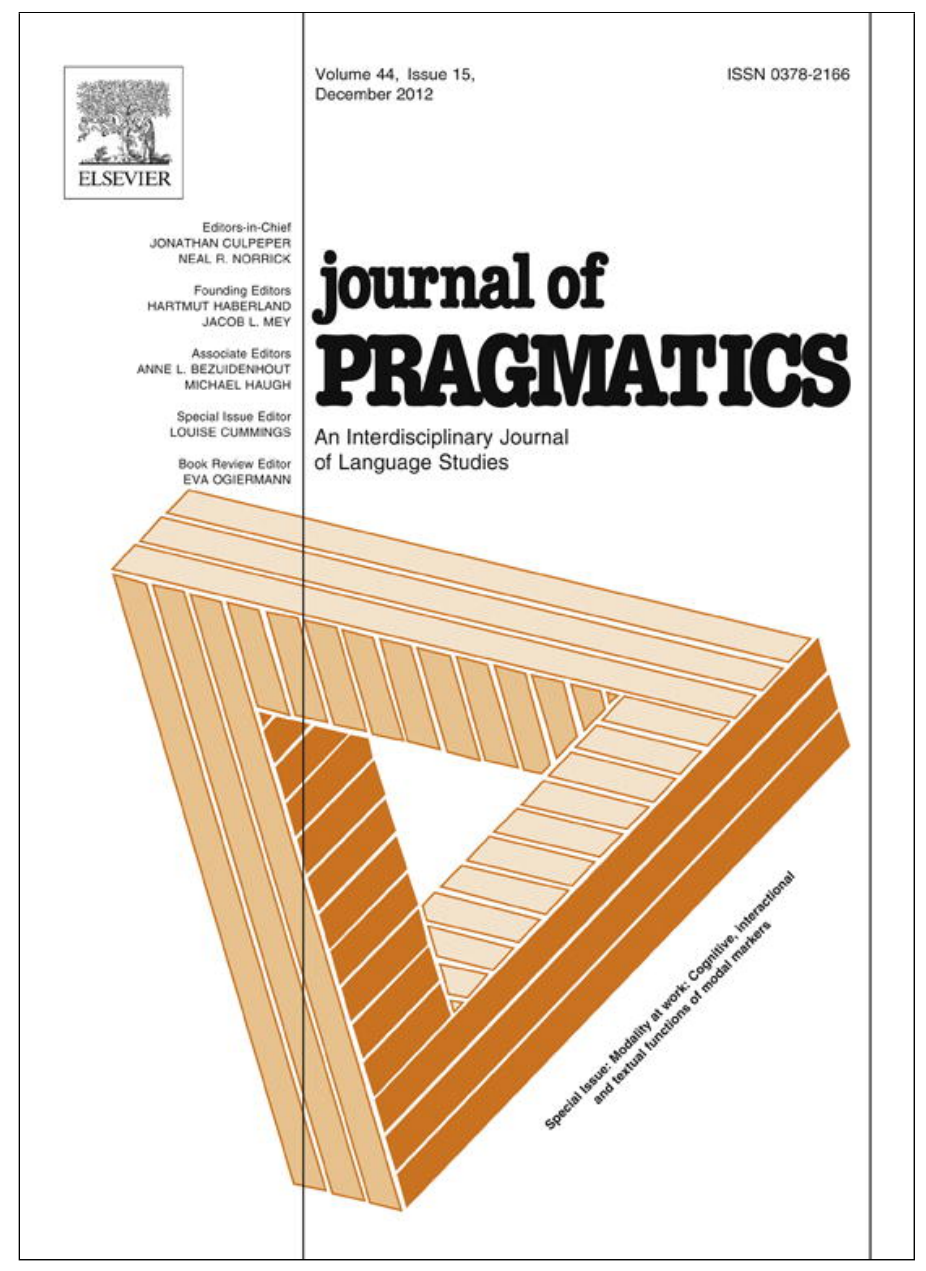

This article appeared in a journal published by Elsevier. The attached copy is furnished to the author for internal non-commercial research and education use, including for instruction at the authors institution and sharing with colleagues.

Other uses, including reproduction and distribution, or selling or licensing copies, or posting to personal, institutional or third party websites are prohibited.

In most cases authors are permitted to post their version of the article (e.g. in Word or Tex form) to their personal website or institutional repository. Authors requiring further information regarding Elsevier's archiving and manuscript policies are encouraged to visit:

http://www.elsevier.com/copyright 


\title{
The evidential meaning of modal parentheticals
}

\author{
Corinne Rossari * \\ University of Fribourg, Domaine Français, 13 av. Beauregard, CH-1700 Fribourg, Switzerland \\ Received 26 September 2011; received in revised form 5 July 2012; accepted 17 September 2012
}

\begin{abstract}
The article explores how the evidential meaning of 'inference', 'perception' and 'hearsay' transmitted resp. by the following French markers: faut croire [one should believe], on dirait [one should say] and paraît [it seems] is related to their parenthetical use. To address this question, we first analyze the syntactic and pragmatic function of these three parenthetical constituents, by showing that their preference for the final position is to be put in relation with a dialogical value. Second, we will see that their evidential meaning can be reconstructed step by step by taking into account such a dialogical value as well as the lexical meaning of the verb they are compounded with. More generally, our study will show that an evidential meaning is not a genuine value, but is obtained by a plurality of factors. Among them, the pragmatic function due to their parenthetical use plays a significant role.
\end{abstract}

(C) 2012 Published by Elsevier B.V.

Keywords: Pragmatics; Syntax; Parenthetical; Evidentiality; Lexicalization

\section{Introduction ${ }^{1}$}

The objective of this article is to highlight a case of evidential ${ }^{2}$ meaning derived from the parenthetical use of modal verbs. We essentially focus our attention on markers built with verbs conveying very different lexical meaning: faut croire [one should believe] built with a verb expressing an obligation 'faut' and a verb expressing an epistemic state 'croire', on dirait [one would say] composed with a dicendi verb used in the conditional mood and paraît [it seems] which consists in an impersonal perceptive verb conjugated at the indicative present. Their parenthetical use in final position obliterates these different lexical meanings and gives rise to a similar evidential value, as illustrated in the following examples ${ }^{3}$ :

(1) À dire du mal ainsi, médire, mépriser, menacer, ça leur faisait du bien, faut croire. To speak ill like that, to despise, to threaten, it made them feel good, one should believe ${ }^{4}$ (Céline, 1932)

\footnotetext{
* Tel.: +412630078 00; fax: +41263009752.

E-mail address: corinne.rossari@unifr.ch.

1 This current study is a contribution to the research project "The evidential system of French and Italian" funded by the SNF (Nos. 101512117645). It extends the work initiated in Rossari (2012) for faut croire, on dirait and parait. The present analysis relies on the syntactic and pragmatic function of these markers, whereas my former research was focused on the interaction between modal and evidential meaning.

2 The notion of "evidential meaning" is used in reference to the way it has been introduced in pragmatics for the analysis of modal markers of different languages, as exposed in the seminal study of Dendale and Tasmowski (2001).

${ }^{3}$ Our corpora are based on any authentic occurrence regardless of diaphasic variation. Therefore we take into account databases, as Frantext (for the author's examples) or Internet (for the spontaneous written occurrences). A study focused on where these ways of saying come from is to be done. However we hypothesize that they occur in written texts with the purpose to imitate the spontaneous language.

${ }^{4}$ The French discourses and expressions are always translated with a word-for-word translation, even when it is not correct in English. In the case of the markers analyzed the word-for-word translation is quite far from the meaning in French.
} 
(2) Les avions sont maintenant tout près. Ils frôlent les arbres, on dirait. The planes are now very close. They nearly touch the trees, one would say (Cavanna, 1979).

(3) Maintenant, je vais chez Pascal. Et après, chez la patronne qui veut me parler, paraît. Now l'm going to Pascal. And after, to the boss who wants to talk with me, it seems. (Duhamel, 1938).

The three markers indicate that the speaker has only indirect evidence for the state of affairs (SoA) expressed in the host utterance.

Our analysis will concentrate on two issues: on the one hand, the syntactic and pragmatic function between the marker and the host clause; on the other hand, the semantics of each marker. Both analyses will allow us to assess how their general evidential meaning (indirect evidence) and their particular one ('inference' for faut croire, 'vague perception' for on dirait and 'weak hearsay' for parait) occur in the way they contribute to the interpretation of the host utterance.

\section{The syntactic and pragmatic function between the marker and the host clause}

\subsection{The similarities and differences with the reduced parenthetical clauses}

The three evidential expressions have many features in common with the reduced parenthetical clauses (RPC) analyzed in Schneider (2007). Some of the French expressions included in Schneider's RPC list are very similar to the items under consideration: "je crois, disons, il faut dire, je dirais, parait-il, me semble-t-il" (p. 78). According to this author, the RPC are:

"neither the main clause nor a subordinate clause, but are inserted into or adjoined to the end of the sentence in a way similar with sentence adverbs. Their position is free and there is no overt syntactic link between them and the host sentence or parts of it. They are related to the host only by adjacency and by the fact that their missing argument can be recovered from the host. As other peripheral elements, they are optional, i.e., they can be added as well as dropped freely without endangering the grammatical acceptability of the host. Nevertheless, they are pragmatically connected to it." Schneider (2007:1).

Our three expressions fit very closely to the latter description. However, they differ on two important points:

(i) They occur in most cases in the final position:

(4) Et c'est même pas bon à manger; le rouge des poissons rouges, c'est du poison, paraît. It is not even good to eat; the red of the red fishes, it is poison, it seems. (Fallet, 1956)

(5) ??Et c'est même pas bon à manger; le rouge des poissons rouges, c'est, parait, du poison ${ }^{5}$ It is not even good to eat; the red of the red fishes, it, it seems, is poison.

A parenthetical such as parait-il [does it seem] $]^{6}$ can be inserted in any position:

(6) C'est, paraît-il, du poison It is, does it seems, poison

(ii) They do not have a missing argument. They can be used as independent utterances:

(7) Est-ce que ça leur faisait du bien de médire, mépriser, menacer? Did it make them feel good to speak ill, to despise, to threaten?

- Faut croire / On dirait / Paraît One should believe / One should say / It seems

The forms with subject inversion are also RPCs according to Schneider, but they cannot be used as independent utterances:

(8) Est-ce que ça leur faisait du bien de médire, mépriser, menacer? Did it make them feel good to speak ill, to despise, to threaten?

??[Faut-il croire / Dirait-on / Paraît-il /Me semble-t-il] Should one believe / Should one say / Does it seem / Does it seem to me

\footnotetext{
5 "??" indicates that there is no attested occurrence of the form and that the sentence sounds odd.

${ }^{6}$ English makes no difference between the form with subject inversion (parait-il) and the regular one (il parait). We will use the interrogative mood in English to mark the difference between the two forms.
} 
Otherwise, most of the criteria listed by Schneider are relevant for our three expressions. The lack of overt link with the host clause, the sententiality and the possible link with a main clause used descriptively are properties shared by our markers. They are not full-fledged clauses, i.e. they are grammatically and pragmatically reduced and expressions with the same verbs can be used as main clauses: il faut croire que $P$ [one should believe that $P$ ] or il faut le croire [one should believe it], on dirait que $P$ [one would say that $P$ ] et il parait que $P$ [it seems that $P$ ].

\subsection{The possible relationships with the host clause}

The authors quoted by Schneider (2007) put forward different hypotheses to explain the syntactic relationship and the pragmatic function of these expressions. While all of them note the lack of an overt link, many authors try to establish a correspondence between the RPC's construction and the same construction used as a main clause. This link is based on the idea that there is some sort of a derivation process between the subordinate structure (Verb that Clause) and the parenthetical one (Clause, Verb). The notion of "recteur faible" ('weak governing verbs') introduced by BlancheBenveniste (1989) and reanalyzed in Blanche-Benveniste and Willems (2007) and Willems and Blanche-Benveniste (2010) is commonly acknowledged to characterize this particular relationship between the two structures. The main idea is that the subordinate clause in the (Verb that Clause) structure can be interpreted as the main content of the whole structure, as pointed out in the seminal work of Urmson (1952). Such an interpretation is consistent with the loss of the subordination link, resulting in the parenthetical use of the verb. RPC is thus seen as maintaining "some kind of relationship with the host at a higher level" Schneider (2007:29). The disagreements regard the nature of the relationship.

Some authors consider that there is an implicit hypotactic relationship between the parenthetical and the host. For instance, Damourette et Pichon (1933) see the "incise" as subordinate clauses:

"Celui-là, dit Lalie en montrant Bernard, n'est plus mon frère. That one over there, says Lalie indicating Bernard, isn't my brother anymore

"Celui-là n'est plus mon frère que dit Lalie en montrant Bernard. That one over there isn't my brother anymore, that says Lalie indicating Bernard"' Schneider (2007:31)

Such an analysis is not relevant for faut croire as an evidential marker, but is possible for parait and on dirait:

(9) Ce n'est plus mon frère, faut croire / on dirait / paraît That one isn't my brother anymore, one should believe / one would say / it seems

(10) \#Ce n'est plus mon frère qu'il faut croire ${ }^{7}$ That one isn't my brother anymore, that one should believe

(11) Pas de gogues ici, qu'il paraît. No restrooms here, as it seems (Degaudenzi, 1987)

(12) Le cœur va lui sauter qu'on dirait. His heart will explode, as one would say (Lacretelle, de Guéritte, T., Sarn [trad.], 1930).

Brinton (2007) sustains, like Damourette et Pichon, that the parenthetical use of I mean could come from an "adverbial finite clause (e.g., as you know in which as has a relative function, or as I see it in which as has a subordinator function)" Brinton (2007:54). However, such an analysis could not be used to characterize the link between faut croire, on dirait, parait and the host clause. No item could be used with comme:

(13) *Ce n'est plus mon frère comme il faut croire / comme il paraît / comme on dirait. ${ }^{8}$ That one isn't my brother anymore, as one should believe / as one would say /as it seems

Brinton finally selects another scenario for explaining the emergence of I mean as a pragmatic parenthetical:

"Initially I mean governs a phrasal element $\{\mathrm{NP}, \mathrm{VP}, \mathrm{AP}, \mathrm{PP}, \mathrm{AdvP}\}$ and has scope within the sentence. The bonds between I mean and the phrasal element are weakened or loosened, and I mean can begin to be postposed to the phrasal element. The phrasal element is then reanalysed as an independent element, and I mean as a syntactically free parenthetical with scope over the sentence. At this point, I mean is extended to the context of clauses and can be pre- or postposed to clausal elements as well, thus acquiring scope over discourse." Brinton (2007:58).

Such an explanation is also plausible for faut croire. It has the capacity to govern a phrasal element which can be expressed by a clitic: il faut le croire. But the presence of the clitic object is never attested when faut croire is used in the final position and if ever used the utterance sounds odd:

\footnotetext{
7 “\#” indicates that the sentence is grammatical, but has another interpretation: ce n'est pas mon frère qu'il faut croire mais mon ami [it is not my brother that we should believe, but my friend].

8 " **" indicates that the sentence is not grammatical. Comme on dirait is possible, but it means "it is a way of saying". It has no evidential meaning.
} 
(14) Rosalie reprit: Rosalie said:

- M. Paul viendra dès l'enterrement fini. Demain à la même heure, faut croire. Mr. Paul will come as soon as the burial is over. Tomorrow at the same time, one should believe. (Maupassant, 1883).

(15) M. Paul viendra dès l'enterrement fini. Demain à la même heure, ??il faut le croire Mr. Paul will come as soon as the burial is over. Tomorrow at the same time, one should believe it.

Parait and on dirait can theoretically govern a phrasal element (on dirait $X /$ il parait $X$ ) but in both cases the phrasal element is either a clause or a reduced clause.

(16) II paraît que Paul est venu. It seems that Paul came

(17) On dirait Paul -> On dirait que c'est Paul One would say Paul -> One would say that it is Paul

Therefore the analysis cannot be the one assumed by Brinton for I mean. For otherwise, it would imply the following scenario:

"I think that he will win > I think he will win > He will win, I think", Brinton (2007:53).

The latter is not adopted for explaining the emergence of $/$ mean as a pragmatic parenthetical. Furthermore, there is no empirical ground to adopt it for explaining the sentence final position of our three expressions: it neither explains the high preference for final position, nor the fact that they are independent clauses whereas parenthetical with subject inversion are not: cf. ex. (8). On the same paradigm of il faut croire que $P$, we can build il faut penser que $P$ [one should think that $P$ ], il faut envisager que $P$ [one should foresee that $P$ ], but none of these clauses has developed a use in sentence final position as the one of faut croire.

(18) II faut envisager que ce n'est plus mon frère One should foresee that that one isn't my brother anymore

(19) ??Ce n'est plus mon frère, faut envisager That one isn't my brother anymore, one should foresee

(20) II faut penser que ce n'est plus mon frère One should think that that one isn't my brother anymore

(21) ??Ce n'est plus mon frère, faut penser That one isn't my brother anymore, one should think

Such a contrast also remains unexplained with the idea that there is a link between the "recteur faible" use and the parenthetical one.

At the pragmatic level the descriptions are more unified. The view of Urmson (1952) - according to which the main function of RPC is to limit speaker's commitment regarding the truth of the asserted proposition - is widely adopted. The position (inserted or final) of the RPC is usually not considered as relevant. Our description will confirm the pragmatic function of mitigation but will show that the position is not irrelevant to fulfill such a function.

Morel and Danon-Boileau (1998) consider parenthesis from a textual point of view. They note that it enables speakers to comment on their discourse (cf. Schneider, 2007: 34).

Our hypothesis will reinforce the latter assumption. We will see indeed that the final position is particularly efficient for adding material that allows the speaker to comment on her/his own discourse. But, in contrast with most studies, we refuse the idea of a link between the parenthetical use of the items analyzed and the notion of "recteur faible" characterizing the ( $V$ that Clause) construction. The use of the same verb in both structures is not a reason to hypothesize some sort of derivation process from the "recteur faible" to the parenthetical use of the same verb. Instead, we assume that the parentheticals are linked to their host at discourse level through a relationship between their dialogical uses as independent utterances.

In other words, we postulate that the expressions used in the structure exemplified by (7) endorse a pragmatic function similar to the one they have when they are used as parentheticals in monological discourses. The preference for the final position is a consequence of this dialogical function. However, we do not exclude that they can be inserted in other positions with a similar function, since such a function becomes part of their meaning.

\subsection{The clues of a link to the host clause at discourse level}

The three evidential markers are lexicalized in the sense that they have partially lost their compositionality. The verb has no inflexion (\#fallait croire [one had to believe]/ \#on dira [one will say]/ \#paraitra ${ }^{9}$ [it will seem]) and the clitics can or have to be removed. As already seen, faut croire is ungrammatical in sentence final position with the clitic object and unattested with the clitic subject. However, parait is attested in both versions in sentence final position (cf. (3)).

\footnotetext{
9 "\#" indicates that the form exists but has not the same function as the original one.
} 
(22) -Bonjour, Lucas, sourit Marie-Andrée, on nous a envoyés ici, tu y passes tous tes après-midi, il paraît. Hello Lucas, says Marie-Andrée, smiling, we were sent here, you spend here all your afternoons, it seems (Lang, 2001)

The three expressions can be used as independent utterances with the same formal properties. They can occur in dialogical contexts to express a reaction to a confirmation request sharing the same features of lexicalization.

(23) «Bonjour petite! Eh! comme tu vas! - Je suis pressée: il y a des jours comme ça! - Faut croire! » "Hello, baby! Well, how fast you go? -I am in a hurry: there are days like that! -One should believe" (Bazin, 1899).

(24) -Hein! Quoi ? II se sauve ! Well! What! He runs away!

Mongicourt, assis sur le canapé, d'un ton blagueur. -On dirait ! Mongicourt, sitting on the sofa, jokingly. -One would say (Feydeau, 1914).

(25) - Et il l'aime toujours cette bonne femme? And he still loves this woman?

- Paraît. It seems. (Queneau, 1944)

The verb has no inflexion:

(26) « Bonjour petite! Eh! comme tu vas! - Je suis pressée: il y a des jours comme ça! - *Fallait croire! » "Hello, baby! Well, how fast you go? -I am in a hurry: there are days like that! -One had believed"'

(27) -Hein! Quoi ? II se sauve ! Well! What! He runs away!

Mongicourt, assis sur le canapé, d'un ton blagueur. -*on dira / *- nous dirions!

Mongicourt, sitting on the sofa, jokingly. -one will say / - we would say.

(28) - Et il l'aime toujours cette bonne femme? And he still loves this woman?

- ?Paraîtrait. ${ }^{10}$ It would seem.

Other lexicalized expressions used as confirmation in dialogical structures, have the ability to occur in the final position. ${ }^{11}$ For instance, among the "weak verbs" (il me semble, [it seems to me] il parait, [it seems] j'ai l'impression, [I have the feeling] on dirait, [one would say] je dirais [I would say]) analysed by Willems and Blanche-Benveniste (2010), j'ai l'impression and il semble (and not il me semble) could be added to our list. Both can be used dialogically or in the final position with the same features of lexicalization:

(29) La fourrure, ce n'est pas tellement ton style, j'ai l'impression. Fur is not really your style, I have the feeling. (Mréjen, 2004)

(30) Je reviens vous embêter car les articles de Reviewer.fr ne sont à nouveau pas pris en compte par Google Actualités depuis ce midi. Y a-t-il des ralentissements ? I am coming back to bother you because the articles of Reviewer.fr are one more time not taken into account in Google Actualities since midday. Is there any slowdown? - J'ai l'impression, oui. I have the feeling, yes.

(https://productforums.google.com/forum/?fromgroups\#!forum/news-fr, 05-25-2012)

j'ai l'impression used as a lexicalized form cannot be modified by peut-être [perhaps]. When the latter is used, it selects the full-fledged interpretation of the construction.

(31) Je reviens vous embêter car les articles de Reviewer.fr ne sont à nouveau pas pris en compte par Google Actualités depuis ce midi. Y a-t-il des ralentissements ? I am coming back to bother you because the articles of Reviewer.fr are one more time not taken into account in Google Actualities since midday. Is there any slowdown? ??J'ai peut-être l'impression, oui I have perhaps the feeling, yes / ?? J'ai peut-être eu l'impression, oui I have perhaps had the feeling, yes

(32) Il y a longtemps que je vis ici. J'ai l'impression...comment dire ?... d'un rétrécissement... ce mot peut sembler péjoratif... Non, rien de tel. C'est très difficile à dire. . I have been living here for a long time. I have the feeling. . . How could I say?... of a narrowing. .. such a word could seem pejorative... No, it is not. It is difficult to say (Bianciotti, 1985)

\footnotetext{
10 "?" indicates that there is no attested occurrence of the form.

11 We do not exclude that many other RPCs could integrate this paradigm, such as je pense, je crois. . The possible extension of the paradigm to any RPC with no subject inversion will be considered in a further study.
} 
(33) Il y a longtemps que je vis ici. J'ai peut-être l'impression...comment dire ?... d'un rétrécissement... ce mot peut sembler péjoratif... Non, rien de tel. C'est très difficile à dire. . I have been living here for a long time. I have perhaps the feeling. . . How could I say?... of a narrowing. . . such a word could seem pejorative. . . No, it is not. It is difficult to say

In the following examples, il semble is lexicalized. It could neither be modified by "peut-être", nor can the tense vary:

(34) - N'a-t-il pas des paquets ? Has he no bag?

-II semble. It seems (Romains, 1913)

??Il semble peut-être It seems perhaps / ??Il a semblé It seemed

(35) - Est-il assez grand, oui ou non, pour savoir ce qu'il a à faire? Is he old enough, yes orno, to know what he has to do?

- II semble. It seems (Romains, 1922)

??Il semble peut-être It seems perhaps / ??ll a semblé It seemed

(36) Et puis, vous avez été recommandé, il semble. And you have been recommended by someone, it seems (Sollers, 1987)

(37) Et puis, vous avez été recommandé, ??il semble peut-être / ??il a semblé. And you have been recommended by someone, it seems perhaps/lt seemed

Instead, II me semble has no feature of lexicalization. When used dialogically, it is interpreted as a full-fledged clause:

(38) - Tu crois que ça signifie que je suis faite pour les femmes ? You believe it means that I prefer women? - Je ne sais pas. II me semble... Qu'en penses-tu ? I don't know. It seems to me... What do you think? (Monferrand, 1991)

(39) - Tu crois que ça signifie que je suis faite pour les femmes ? You believe it means that I prefer women? -Je ne sais pas. II m'a semblé / II me semble peut-être... Qu'en penses-tu ? I don't know, It seemed to me/ It seems perhaps to me... What do you think?

These tests show that the three constructions, when used dialogically as independent utterances, share exactly the same features as the expressions used as RPC in monological discourses. So instead of establishing a link at a syntactic level with the host clause, we establish a link at the discourse level. The speaker uses the RPC in monological discourses as a tool to give a dialogical flavor to her/his discourse. It allows the speaker to react to his/her own discourse and to confirm the SoA previously expressed. In this sense, it fulfills the function of 'comment' highlighted by Morel and DanonBoileau (see above). The final position is a consequence of the fundamental dialogical value of these RPCs. The way they work make them appear to be similar to the clauses of "justifications confirmatives" [confirmative justifications] identified by Béguelin (2010) in the inventory of the functions of paratactic sequences: "[ . . ] la seconde clause [qui correspondrait à nos RPC] reprend en écho, mais de manière abrégée, le contenu de la première, produisant un effet de confirmation ou d'insistance" (Béguelin, 2010:21). [The second clause [which corresponds to our RPC] repeats in a summarized form the content of the first one, producing a confirmative or an emphatic effect].

However, in the case of our RPCs, there is no explicit reiteration of the content of the first clause. The use of the clitic object le [if], which indicates the repetition of the content, makes the sentence ill formed, as already seen with example (15). This is because the presence of the clitic would underline a textual link between both clauses which would cancel their fundamentally dialogical relationship. In short, we assume that the salient properties of the evidential RPCs are their ability to stress a link at the discourse level. The host clause is conceived as a confirmation request and the evidential RPC is used to address an answer to this request. Such a discourse process involves a mitigation of the host clause: the confirmation expressed by the RPC jeopardizes the reliability of the SoA expressed in the host clause. ${ }^{12}$ It is through this function that they acquire an evidential value, as it will be seen in the next section.

\section{The evidential value}

\subsection{The contribution of the dialogical function to the general evidential meaning}

The dialogical features of these expressions determine in part their evidential meaning. In 'real' dialogical contexts, they allow the speaker to confirm a SoA by making an allusion to the common knowledge. In this dialog:

\footnotetext{
12 The discourse pattern - rhetorical question and answer - crystalized with some RPCs is a very common way of introducing topics in monological discourses: "18 mai 2012 - Aurait-il surestimé ses capacités vocales? Eh bien oui!" Would he have overrated his voice? Well, yes! (http://www.lexpress.fr/culture/musique/donna-summer-I-hommage-2-0_1115905.html 05-18-12). The speaker pretends to doubt the validity of the idea expressed in the question, and then, she/he answers the question he/she has herself/himself asked.
} 
(40) - Mince alors, fit-il, l'autre salaud lui a raconté ? Damn, he says, the bastard has told him the story?

- Faut croire. One should believe (Clavel, 1962).

Faut croire or any other expression (on dirait, parait, il semble, j'ai l'impression) conveys an interpretation where the speaker confirms the SoA expressed in the question by making an allusion to some shared knowledge. If the speaker knows that someone told the story to the protagonist because he/she was present during the discussion, she/he would not say faut croire / on dirait / parait /j'ai l'impression or il semble to answer the question. For instance, these forms could not be used in the following dialog:

(41) - Mince alors, fit-il, l'autre salaud lui a raconté ? Damn, he says, the bastard has told him the story? -??[Faut croire. / On dirait. / Paraît / J'ai l'impression / Il semble], j'y étais. One should believe / One would say / It seems / I have the feeling / It seems, I was present

The speaker could use oui [yes] instead:

(42) - Mince alors, fit-il, l'autre salaud lui a raconté ?

- Oui, j'y étais. Yes, I was present

To sum up, the evidential meaning of faut croire / on dirait / parait / j'ai l'impression or il semble can confirm a SoA by indicating an indirect shared knowledge.

In monological contexts, the evidential value is nearly identical to the one in dialogical contexts. The speaker indicates that he/she has indirect shared evidence to communicate what is said in the host utterance. Such an indication is a projection of their dialogical use. The following constraints characterizing their use add supporting evidence to this evidential meaning.

1. The SoA modified by them is a conjecture not a fact that can be directly observed.

(43) [Paul est devant moi] ??Paul est arrivé, faut croire / on dirait / paraît / j'ai l'impression / il semble. ${ }^{13}$ [Paul is in front of me] Paul has arrived, one should believe...

2. The SoA cannot be an inference that only the speaker is able to make:

(44) Je me disais: "Si Philippe sait que Petit Titou a vu l'intérieur du coffre, il doit être inquiet, il est resté dans les parages pour l'observer. [ . . ]"I was thinking: "if Philippe knows that Petit Titou has seen what is inside the chest, he must be worried; he stayed around somewhere to keep an eye on him (Japrisot, 1966).

(45) Si Philippe sait que Petit Titou a vu l'intérieur du coffre, il est inquiet, ??[faut croire / on dirait / paraît / j'ai l'impression / il semble] il est resté dans les parages pour l'observer. I was thinking: "if Philippe knows that Petit Titou has seen what is inside the chest, he is worried one should believe ...; he stayed around somewhere to keep an eye on him

3. They cannot be inserted in an utterance that the speaker refuses to endorse directly afterwards:

(46) On dit que la révolution a supprimé la noblesse; mais c'est tout le contraire, elle a fait trente-quatre millions de nobles... One says that the revolution has abolished the nobility; but on the contrary it made thirty-four millions of noblemen (Michelet, 1846).

(47) ??La révolution a supprimé la noblesse, paraît /on dirait / faut croire / j'ai l'impression / il semble; mais c'est tout le contraire, elle a fait trente-quatre millions de nobles The revolution has abolished the nobility one should believe ...; but on the contrary it made thirty-four millions of noblemen

On dit que, which alludes to another source from the speaker, enables her/him to reject the point of view borrowed, in his/her subsequent discourse. This is not the case of our markers. They mean that the speaker does endorse what he/she communicates in the host utterance, even if he/she puts some distance with it.

\footnotetext{
${ }^{13}$ An ironic interpretation makes the example natural, but in this case the speaker makes fun of Paul acting as if he/she has not noticed his presence.
} 
All these constraints are consequences of their basic dialogical function. The host clause should be interpreted as an assessment to be confirmed. Therefore, it cannot be a personal inference from the speaker, since it makes no sense to confirm one's own inferences. It can neither be a direct perception, because it cannot be interpreted as an assessment to be confirmed. Finally, it cannot be an utterance that the speaker refuses to endorse in her/his following discourse, because our markers indicate that the speaker confirm the information conveyed in the host clause. These characteristics are common to all these markers. But each of them also expresses some particular evidential meaning that we will be examined in the next section.

\subsection{The contribution of the semantics of the verb to the evidential meaning of each RPC}

The confirmation conveyed by faut croire is based on an indication that the SoA can be assumed because it is funded on obvious clues. This is why the RPC seems to endorse an evidential meaning of 'inference'. For instance, in the following examples, the speaker comments truisms with faut croire:

(48) On a ce qu'on mérite faut croire ! We have only what we deserve, one should believe! (http://blogues.lapresse.ca/therrien/2012/04/12/mongrain-sen-va/ 04-13-2012)

(49) Jamais je n'aurais imaginé revivre un certain temps en sa présence, mais il ne faut jamais dire jamais faut croire. I would never have imagined to live again some time with him, but one should never say never one should believe (http://mamancoach.blogspot.ch/2011_05_01_archive.html 05-14-2011)

The easy use of faut croire with truisms is due to the fact that it allows the speaker to act as if the SoA were worth to be said. Without faut croire, the utterance or "on a que ce qu'on mérite" [we have only what we deserve] or "il ne faut jamais dire jamais" [one should never say never] is interpreted as non-informative. With faut croire, it is reinterpreted as an assumption (even if the SoF expressed is self-obvious) that the use of faut croire confirms retroactively.

The indication of obviousness is linked to the lexical value of the verb falloir, always present in the RPC. The sequence with both clitics (subject and object) il faut le croire [one should believe if] can be used with a compositional meaning. In such a use, it expresses the necessity to believe in a particular SoA, because of the presence of clues (mentioned or not) that prove the truth of it.

(50) - Est-ce que, par hasard, pensais-je, j'en serais tombé amoureux aujourd'hui, sans le savoir ? II faut le croire, puisque voilà Huriel qui m'y pousse, et dont l'œil aura saisi la vérité sur ma figure. Did by any chance, I was thinking, I fall in love with her today, without knowing it? One has to believe it, because here is Huriel who makes me do it, and whose eye will have noticed the truth on my face (Sand, 1865).

The clitic pronoun le [if] refers to the content of the question and the clues on which the answer by "il faut le croire" is based are given just after since. The necessity verb falloir has its full lexical value. When the sequence is used as a lexicalized item, the obviousness meaning stands in for the necessity nuance.

The confirmation expressed by on dirait is based on a sensorial perception (visual in most cases). This is why the RPC seems to endorse an evidential perceptive meaning. When the speaker communicates an assessment that can only rely on a visual perception, on dirait is more natural than the two other evidential markers. In the following context, the speaker looks at her friend and thinks that she looks pregnant.

Mais tu es enceinte, on dirait! But you are pregnant, one would say

Using faut croire ou parait would be very strange in this context:

(52) Mais tu es enceinte, \#[faut croire / paraît $]^{14}$ ! But you are pregnant, one should believe / it seems

In the next example, the context indicates that the SoA is obtained by a physical perception.

(53) Je retourne pas à la maison. Les murs tremblent comme tout. J'ai trop peur que les plafonds me dégringolent dessus. I don't come back home. The walls are shaking. I am too afraid that the roof might fall over me.

- Ça se calme, on dirait. It is getting quiet, one would say (Bory, 1945)

\footnotetext{
${ }^{14}$ Both of them could be used but with a different interpretation: faut croire indicates that the clue is not what the speaker has observed but some other indication that leads naturally to this remark. Parait does not communicate any indication on the clue on which the speaker bases his/her remark.
} 
Neither faut croire nor paraît are natural in such a context:

(54) Je retourne pas à la maison. Les murs tremblent comme tout. J'ai trop peur que les plafonds me dégringolent dessus. I don't go come back home. The walls are shaking. I am too afraid that the roof might fall over me. - Ça se calme, ??[faut croire / paraît]. It is getting quiet, one should believe / it seems

In the example below, an acoustic perception is at the origin of the information:

(55) Je colle l'oreille. Plus rien...[. . . ]. Une fenêtre s'ouvre tout à coup. Au-dessus de nous, on dirait. I am listening. No more noise. Suddenly, a window opens. Upstairs, one would say (Boudard, 1963).

The use of faut croire or parait cancels the acoustic source leading to the conjecture:

(56) Je colle l'oreille. Plus rien...[...] Une fenêtre s'ouvre tout à coup. Au-dessus de nous, faut croire / paraît. I am listening. No more noise. Suddenly, a window opens. Upstairs, one should believe/ it seems

The perception conveyed by on dirait comes from its dicendi meaning. On dirait literally communicates what one should say, if a particular SoA were noticed. The conditional brings an indication of caution which gives rise to the meaning of vague feeling.

(57) Si l'on savait cela, l'on dirait que Madeleine est folle. If we knew this, we would say that Madeleine is crazy (Gautier, 1836)

In this example, on dirait is interpreted as a dicendi verb used in the conditional mood. But without the if-clause, it can also be interpreted as an evidential verb. In the latter case, the interpretation corresponds to: on a Iimpression que ... [we have the feeling that. . .]. In example (2) on dirait is used as a RPC, but it is also ambiguous. It can be interpreted as "si on voyait les avions de près, on dirait qu'ils frôlent les arbres" [if were looking closely at the planes, we would say that they nearly touch the trees] or as an evidential marker. In this case it is equivalent to the RPC "j'ai l'impression": "Les avions sont maintenant tout près. Ils frôlent les arbres, j'ai l'impression" [The planes are now very close. They nearly touch the trees, I have the feeling]. Since the sequence is lexicalized, the dicendi meaning is over and the RPC expresses a similar meaning to j'ai l'impression.

The confirmation expressed by paraitt, is based on a visual perception whose origin is dissimulated. In a context where the source is a precise clue (for instance the speaker sees the light in Paul's flat) she/he would not say:

\section{(58) \#Paul est là, paraît. Paul has arrived, it seems}

With parait the utterance is interpreted as alluding not to the light, but to some other information, the source of which remains undetermined. Such an evidential meaning is similar to a weak 'hearsay'. On dit que for instance, which conveys a 'real' 'hearsay', allows the speaker not to endorse the truth of the propositional content. Such an interpretation is not possible with paraitt, as seen in example (47). The example below shows that parait does not allude to the visual perception of the speaker but to some information whose origin is not communicated.

(59) C'est ainsi qu'elle prit l'habitude de venir le voir à toute heure. A quelque temps de là, il advint qu'elle redescendit avec une de ces babioles qu'on les porte comme bracelets, c'est le mot pour cette sorte d'objet, même qu'il en avait d'enroulés à ses bras, le mort, un bracelet wampum, et un beau, paraît. Thus she used to come and see him, at any time. Later, she sometimes went back downstairs with some trinket that we wear like bracelets, that is the word for this sort of thing, the dead had one of these around the arm, a bracelet wampum, and a nice one, it seems. (Aragon, 1926).

The next example highlights the ambiguous interpretation of paraît between perceptive and evidential meaning:

(60) - T'es un sacré tireur, gars Claudius, paraît bien! You are a hell of shooter, chap Claudius, it seems well (Chevallier, 1934)

The perceptive meaning is still present with the use of bien, but paraît can also be interpreted as conveying a weak hearsay. 
The indetermination of the perception conveyed by the evidential meaning of parait comes from the impersonal use of the verb. Paraitre used as a full-fledged verb indicates that the speaker has a personal interpretation of her/his visual perception. In an utterance such as:

\section{Paul paraît pâle Paul looks pale}

the speaker says that he/she has the personal assessment of interpreting the color of Paul's face as pale. What is surprising with the evidential value is that parait no longer indicates the perception of the speaker. In the example below:

\section{Paul est pâle, paraît Paul is pale, it seems}

the perception of Paul's face cannot be interpreted as the one of the speaker. She/He conveys an assessment that she/ he has not established herself/himself. Such an apparent semantic change is due to the impersonal use of the verb paraitre. The person at the origin of the perception disappears. When one says "Paul paraît pâle" [Paul seems pale], the hearer knows that the speaker is at the origin of the visual perception. But when one says "ll paraît que Paul est pâle", [it seems that Paul is pale] the hearer has no information on the origin of it. This is why the evidential meaning corresponds to a weak hearsay, as perfectly illustrated by the example below:

(63) [ . . ] mais cette maison appartenait donc à M. De Saint-Méran avant que vous ne l'achetiez, Monsieur le comte ? -Il paraît que oui, répondit Monte-Cristo. But this house belonged to Mr. De Saint-Méran before you bought it, Mr. the Count? - It seems that yes, answered Monte Cristo.

-Comment, il paraît! Vous ne savez pas à qui vous avez acheté cette maison? How, it seems! You do not know from whom you bought this house?

-Ma foi non, c'est mon intendant qui s'occupe de tous ces détails. Well, no, it is my treasurer who takes care of these details. (Dumas Père, 1846)

The reaction (How, it seems!) of the speaker shows that he is fully aware that Monte Cristo, using il parait que, dissimulates his knowledge. Yet, the information introduced by il parait que is still not dubious, because the idea of visual perception remains present. It explains why the speaker cannot reject the SoA afterwards cf. (47).

In short, the evidential meaning of each marker is conveyed, on one hand, by their dialogical properties and on the other hand, by the lexical meaning of their verb.

\section{Theoretical issues}

Our study has shown that the evidential meaning cannot be considered as a primitive semantic value, but occurs in relation to a plurality of factors. Syntax, semantics and pragmatics play a role in the constitution of this meaning.

On the one hand, the final position of the RPCs analyzed is consistent with the illocutionary function of confirmation on an assessment, which gives rise to an evidential meaning of indirect shared knowledge. One can only confirm a SoA that he/she has not established by himself/herself. This function obliterates the different lexical meaning of each marker. Therefore none of these RPCs can occur in a context where the speaker has a direct access to the reported knowledge cf. (43).

On the other hand, the semantic kind of modality allows them to convey one particular evidential meaning: 'obviousness' for faut croire which gives rise to an inferential evidential meaning, 'vague perception' for on dirait which gives rise to a perceptive evidential meaning, and 'dissimulation of the exact source' for parait, which gives rise to a weak hearsay evidential meaning.

\section{Acknowledgements}

I thank the two anonymous reviewers for their helpful suggestions and constructive criticisms of an earlier draft.

\section{References}

Béguelin, Marie-José, 2010. Noyaux prédicatifs juxtaposés. In: Béguelin, M.-J., Avanzi, M., Corminbœuf, G. (Eds.), La parataxe, Tome 1. Lang, Berne, pp. 1-34.

Blanche-Benveniste, Claire, 1989. Constructions verbales "en incises" et rection faible des verbes. Recherches sur le Français Parlé 9, 53-73. Blanche-Benveniste, Claire, Willems, Dominique, 2007. Un nouveau regard sur les verbes faibles. Bulletin de la Société Linguistique de Paris 102 (1), 217-254. 
Brinton, Laurel J., 2007. The development of I mean: implications for the study of historical pragmatics. In: Fitzmaurice, S., Taavitsainen, I. (Eds.), Methods in Historical Pragmatics. Mouton de Gruyter, Berlin, pp. 37-80.

Damourette, Jacques, Pichon, Edouard, 1933. Des mots à la Pensée. Essai de Grammaire de la Langue Française. 1911-1933. Tome Troisième: Morphologie du verbe, Structure de la Phrase Verbale, Infinitive. D'Artrey, Paris.

Dendale, Patrick, Tasmowski, Liliane, 2001. Introduction. Evidentiality and related notions. Journal of Pragmatics 33 (3), $339-348$.

Morel, Mary-Annick, Danon-Boileau, Laurent, 1998. Grammaire de L'intonation. L'exemple du Français. Ophrys, Paris.

Rossari, Corinne, 2012. Valeur évidentielle et/ou modale de faut croire, on dirait et parait. Langue Française 173, 65-81.

Schneider, Stefan, 2007. Reduced Parenthetical Clauses as Mitigators. Studies in Corpus Linguistics 27. Benjamins, Amsterdam/Philadelphia. Urmson, James O., 1952. Parenthetical verbs. Mind 61, 480-496.

Willems, Dominique, Blanche-Benveniste, Claire, 2010. Verbes 'faibles' et verbes à valeur épistémique en français parlé: il me semble, il paraît, j'ai l'impression, on dirait, je dirais. In: Iliescu, M., al, (Eds.), Actes du XXVe Congrès International de Linguistique et de Philologie Romanes, Septembre 2007, Tome IV, De Gruyter, Innsbruck, pp. 565-579.

Corinne Rossari is Associate Professor of French linguistics at the University of Fribourg (Switzerland). She has published and edited several books on linguistic change and discourse markers. The latest are Grammaticalization and Pragmatics: facts, approaches, theoretical issues (Studies in Pragmatics 5, Elsevier, 2009), and Les moyens détournés d'assurer son dire (Presses de l'Université de Paris-Sorbonne, 2007), both written with the collaboration of her Ph.D. students (Anne Beaulieu-Masson, Corina Cojocariu, Anna Razgouliaeva, Claudia Ricci, and Adriana Spiridon). Her research interests lie mainly within the fields of pragmatics, semantic changes, rhetoric, argumentation and varieties of French. 